\title{
Construction of College English Ecological Classroom Under the Background of Big Data
}

\author{
Xiaojuan Liu ${ }^{1, *}$ and Xiaochong Sun ${ }^{2}$ \\ ${ }^{1}$ School of Foreign Languages, Lanzhou Institute of Technology, Lanzhou, Gansu 730000, China \\ ${ }^{2}$ School of Foreign Languages, Ning Xia Normal University, Guyuan, Ningxia 756000, China \\ *Corresponding author. Email: xiaojuanliu@qq.com
}

\begin{abstract}
The construction of college English ecological classroom is related to the stimulation of students' interest in learning, the establishment of harmonious relationship between students and teachers, the exertion of students' initiative, and the entertainment included in teaching, which is the mainstream teaching concept at present. From an ecological perspective, it analyzes the relationship between students and teachers and discusses the impact of classroom environment on students' learning, expecting to create a harmonious and comfortable learning environment and realize the friendly interaction between teaching and learning, which is also the focus of education reform in the era of big data. Based on the background of big data, this work actively discussed the construction of college English ecological classroom, and put forward effective construction ideas and measures based on discussing its teaching advantages and present situation, which will promote the effectiveness of college English teaching.
\end{abstract}

Keywords: Big data; College English; Ecological classroom; Construction

\section{INTRODUCTION}

Under the background of big data, the ecological teaching of college English has attracted much attention, which pursues "three unification" in teaching. First, it is necessary to pursue the unity of overall correlation and dynamic equilibrium. Second, it is necessary to pursue the unity of openness and interaction. Third, it is necessary to pursue the unity of difference and standard [1]. The ecological teaching model aims to analyze the students' language learning situation and the existing language environment based on different dimensions, explain the language and its teaching in many dimensions focusing on the elements of language itself, teachers, students and environment, and finally construct a balanced and friendly teaching state through sorting out the ecological relationship among various elements.

\section{ADVANTAGES OF ECOLOGICAL TEACHING MODE IN COLLEGE ENGLISH UNDER BIG DATA CIRCUMSTANCE}

\subsection{Bringing out Innovative Teaching Theory Research and Practice}

Under the big data time, the ecological teaching mode of college English has a unique concept and connotation of science and education, which is not a simple superposition of traditional teaching and information teaching in big data time, but also advocates the deep integration of the two, especially emphasizing the two-way flow of teaching information. Students can take the initiative to learn with full of interest in English, and teachers can take the initiative to carry out teaching reform with full of responsibility and enthusiasm for teaching. The big data based ecological teaching mode of college English has realized three levels, including teaching equipment level, classroom activity organization level and teaching achievement evaluation level. For constructing an good ecological teaching circle, it is necessary to update the teaching equipment [2]. Colleges should provide relatively stable ecological learning exchange space for students to learn independently. At the organizational level of classroom activities, teachers and schools should always focus on the number of video clicks of students, make clear the advantages of students' individual development, and guide their future development direction. At the level of teaching evaluation, it is necessary to face up to a series of problems, focus on solving the key problems such as the lack of students' initiative in independent learning and teachers' interest in teaching, optimize and adjust the teaching plan and teaching model, so as to effectively connect the training of teaching talents with the social needs [3]. 


\subsection{Promoting Professional Development of Teaching and Technology for Teachers}

Although the big data era has impacted English teaching significantly, it also enlightens teachers to improve their professional skills to adopt to the trend of the times. College English teachers should have the initiative consciousness of information technology learning, which is also a key step to improve their self-skills and literacy. Teachers should not only learn technology, but also design information technology based English teaching. They should adhere to the student-oriented concept in teaching. College English teachers, only master the big data era of information technology to ensure the specialization of teaching orientation. Only when college English teachers master the information technology in the era of big data can they ensure the professionalization of teaching orientation. The learning of teaching technology is in many aspects, including multimedia information collection technology and micro-lesson making technology [4].

\subsection{Innovating the College English Teaching Mode}

The big data era brings about the reform of college English teaching, and the social influence of the media in the new period is constantly improving. Under this background, MOOC and micro-courses, which emphasize independent learning, have attracted much attention. With the help of mobile terminals, students can learn across time and space, and communicate with teachers freely and timely based on the teacher-student interaction platform. The big data era also gives teachers rich development space to help them obtain massive teaching resources support. Therefore, the implementation of the ecological teaching mode of college English needs to maintain an open mind, draw on the high quality educational resources in the big data era, maintain the dynamic update of college English information, drive the teaching initiative of teachers, the teaching subject, and strengthen the cultivation of independent learning and innovation ability of students, the studying subject [5]. Based on paying attention to teachers and students, it is necessary to focus on the negative reaction of ecological subject relation to learning environment. Only through the coordination, interaction and benign operation of teachers, students and the environment, can college English teaching have more ecological care value and practical teaching effect.

\section{NECESSITY AND URGENCY OF ECOLOGICAL TEACHING OF COLLEGE ENGLISH}

Big data based college English teaching calls for the construction of teaching ecological circle more urgently. A series of problems brought about by the era of big data, such as the imbalance in the structure and function of college English teaching, the imbalance in the coordination between ecological subjects, and the imbalance between ecological subjects and technologies, make the construction of the teaching ecosystem urgent. In the construction of specific teaching ecological circle, it is encouraged to develop teachers' information technology literacy, create a more ecological and harmonious teaching environment with the help of the transformation of teaching ideas, and promote the construction of multidimensional interactive classroom. Making the relationship between teachers and students more harmonious is the inevitable requirement of college English teaching based on the education reform in the era of big data, and is also the internal requirement of the ecological and sustainable development for college English teaching.

\section{THE SPECIFIC PERFORMANCE OF ECOLOGICAL IMBALANCE OF COLLEGE ENGLISH TEACHING UNDER THE BACKGROUND OF BIG DATA}

A total of 110 questionnaires were distributed to two classes of freshmen and 104 questionnaires were collected. After that, 95 valid questionnaires were selected, and 20 questions were set up. The questions mainly covered the three main ecological factors of ecological classroom, which are teaching environment, teachers and students. The purpose of this study is to investigate the ecological status of English reading classroom teaching in junior high school. After systematic analysis, three main manifestations of ecological imbalance in college English teaching are also clarified.

\subsection{Analysis of Imbalanced Structural Optimization Function}

Under the background of the big data era, college English teaching has obvious information characteristics, and the impact of information technology on the traditional teaching mode means that the original relatively balanced and stable teaching structure has been broken. College English is generally taught in large classes, which is limited by the number of students and the teaching environment [6]. However, in the actual English teaching, teachers are also burdened with great teaching pressure, and students feel more passive and boring in learning. The result of question 1 of the questionnaire "Are you happy and satisfied with the English learning atmosphere in the class? A. always; B. Often; C. Half; D. Rarely/unsatisfied" shows that $32 \%$ of the students are "always" happy and satisfied with the English learning atmosphere in the class, $19 \%$ of the students are "often" satisfied with the atmosphere of English learning in the class, $27 \%$ of the students choose the "half" option, and $22 \%$ of the students are "rarely" or unsatisfied with English learning atmosphere, which is shown in Fig. 1. It can be seen that in 
English classroom teaching, teachers still maintain their dominant position and adopt a relatively single teaching method, so the teaching atmosphere is dull, the class is not active enough, and the imbalance of ecological structure optimization and function is serious.

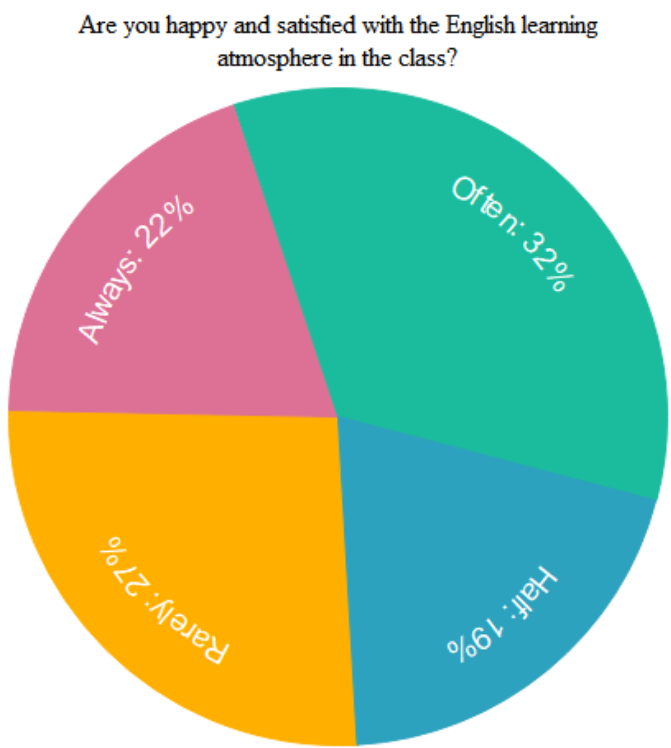

Figure 1 A Survey of Students' Feeling about English Learning Atmosphere in Class

\subsection{Analysis of the Imbalance of Coordination Function Between Subjects}

With the rapid development of technology in the era of big data, the implementation of ecological teaching mode of college English should pursue the balance between "teaching" and "learning", that is, the relationship between teachers and students. However, the existing contradictions in college English make the coordination between the two main bodies appear "cracks". The statistical result of question 14 "English teachers understand the English foundation, learning ability and learning needs of class students: A. Always; B. Often; C. Half; D. Rarely", which is shown in the following chart. It can be seen that $45 \%$ of the students think that teachers "always" understand the basic English and learning needs of class students, $25 \%$ of the students choose the "often" option, 20\% and $10 \%$ choose the "rarely" and "no" options, as shown in Fig. 2. It can be seen that college English teachers face many students and the teaching pressure increases, which makes them unable to pay special attention to the individual in teaching, nor can they do well in the training and guidance of professional English talents according to the current training orientation of innovative talents, leading to the gradual decline of students' interest in English learning. Although the innovation of teaching methods brought by the big data era provides convenience for teaching, it also puts forward higher requirements for teachers, management and supervision of teaching. When teachers strictly supervise students, it will aggravate the imbalance of the relationship between education subjects [7].

Do English teachers understand students' English foundation, learning ability and learning needs?

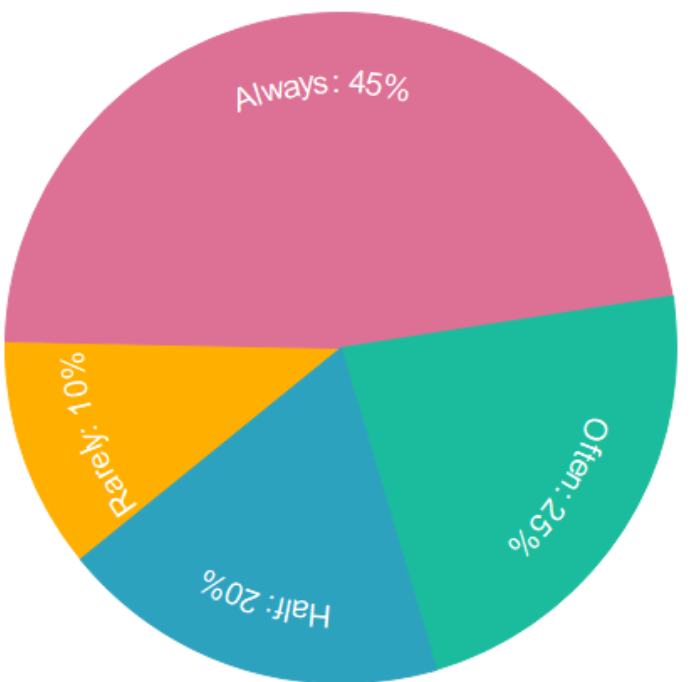

Figure 2 Teacher's Survey of Individual Concern and Understanding

\subsection{Analysis on the Imbalance Between Ecological Subjects and Information Technology in the Era of Big Data}

Teachers are the organizers of classroom teaching and the imparting of knowledge. Teachers should shoulder the responsibility of integrating information resources and guiding the application of information technology. Teachers have the responsibility to construct a relatively balanced ecological English classroom. As another participant in English ecological classroom, students' information literacy is generally low. Although most students have accepted basic computer courses, the technology development and renewal of big data era is fast. The basic operation skills of students cannot cope with the ever-changing technological changes in the era of big data. Therefore, students have poor integration ability in the networked ecology class and the effect of independent learning is not ideal. The statistical result of question 10 "Teachers can use modern teaching media, such as computers and projectors to assist reading teaching: A. Always; B. Often; C. Half; D. Rarely" is shown in Fig. 3. It can be seen that $37 \%$ of the students think that teachers always use multimedia teaching equipment to assist reading teaching, $23 \%$ of the students choose that teachers often use multimedia teaching equipment to assist teaching, only $28 \%$ and $12 \%$ choose "rarely" and "no" options respectively [8]. In terms of the current application of big data era, it is still a big challenge for some teachers to skillfully use the technologies in the era of big data. For many teachers, their application of information technology is limited to the use of office software. 
Do teachers use modern teaching media, such as computers and projectors to assist reading teaching?

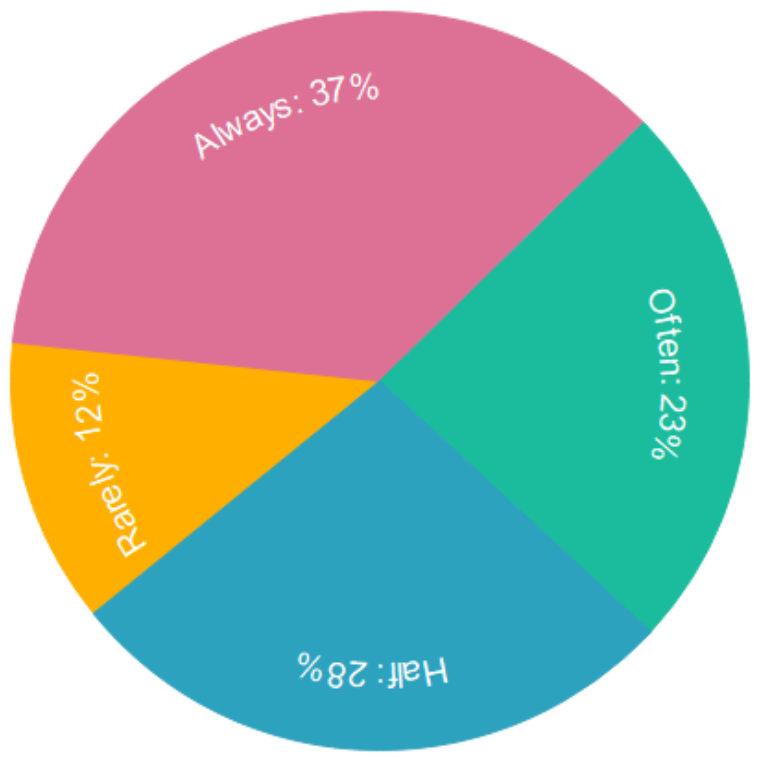

Figure 3 A survey of teachers on the use of multimedia technology

\section{CONSTRUCTION OF ECOLOGICAL TEACHING MODE OF COLLEGE ENGLISH TEACHING IN THE ARA OF BIG DATA}

\subsection{Strengthening Ecological Literacy and Innovating the Concept of Teaching and Learning}

Based on the background of the reform in the big data era, the reorganization and optimal allocation of educational resources are put into practice. In the era of big data, it has the function of efficient dissemination of information, which also makes information exchange get rid of the limitation of time and space. With the development trend of the interconnection of all things, people can receive and transmit information freely with the help of mobile terminals, which also puts forward higher requirements for teachers and students' information technology literacy. In order to promote the construction of the ecological circle of college English teaching, the construction of information technology literacy must follow up with the rapid upgrading of technology. Therefore, teaching should focus on the improvement of information literacy of teachers and students in the era of big data, complete the effective retrieval of resources with the improvement of information literacy, create a harmonious classroom, and lay the foundation for ecological balance of teaching. The teaching idea is the forerunner of teaching action, therefore, it is necessary to change the teaching idea, liberate from the solidified normal teaching mode, abandon the untimely teaching idea and method, use the open and inquiry teaching method, and at the same time cooperate with each kind of rich and colorful education training. It should guide teachers and students on technical literacy, organize and carry out various skills competitions, so as to ensure that the information literacy of teachers and students reaches the ideal level, adjust and improve the information literacy defects exposed in the competition.

\subsection{Creating a Harmonious Ecological Teaching Environment with Simultaneous Measures}

College English teaching puts forward specific requirements for students' language observation, input and learning training. The technology of big data era makes students' language observation, input and learning training more convenient, which also lays the foundation of college English ecological teaching mode. In the creation of network ecological teaching environment, it is necessary to pay attention to the cultivation of students' personality, make them have the ability and motivation of autonomous learning, create a relatively harmonious and balanced teaching environment, and enhance the interactive exchange of various elements in the environment. Students effectively absorb knowledge, find problems, and teachers effectively guide teaching. College English teaching is a dynamic process with the uncertainty of learning process and the free expansion of knowledge content. Usnder the action of big data era, teachers, based on the information education model, make a detailed analysis of the relevance of various elements of classroom teaching to create an organic classroom as a whole. For English vocabulary teaching, teachers integrate the basic knowledge of English vocabulary teaching with the support of the new teaching method, create a word learning ecological teaching environment for students, encourage students to remember and think independently, and teachers appropriately point out and guide them to teach students effective ways of memorizing words. Teachers carry out multidimensional assessment to students' word memory situation, control student's word learning state in time, let students carry on the English word study more planned and more effective. In the process of English word teaching, teachers supervise and guide students dynamically, while students enjoy the initiative of English vocabulary learning. In order to improve the effectiveness of English teaching, the teachers, students and the teaching environment are in a relatively balanced state among various elements, and even teaching benefits each other.

\subsection{Building Multidimensional Interactive Ecological English Classroom}

College English ecological teaching is a process of interaction and influence between teachers, students and 
teaching environment. The creation of effective ecological teaching environment makes teaching more harmonious. Specifically, the construction of ecological classroom needs to focus on pre-class, in-class and after-class. The pre-class stage provides perfect multimedia teaching equipment support for the teaching, provides corresponding teaching material content, and completes the early preparation work of the environment creation. The in-class stage focuses on building a harmonious external environment and equal teacher-student relationship with benign interaction as the core. After-class stage is mainly group cooperation. The group is in a stable state of cooperation, in which team members brainstorm and work together to complete the assigned learning tasks [9]. Under the background of big data era, the implementation of college English ecological teaching mode also has more or less impact on the original ecological pattern of classroom teaching. In the era of big data, a large number of information devices are used in teaching, and the communication and interaction between teachers and students are relatively reduced. Students and teachers prefer the application of information devices. To solve this problem, for one thing, teachers should innovate information technology teaching methods and pay attention to the improvement of students' autonomous learning ability; for another, information technology should be used reasonably to avoid the problem of uncoordinated ecological subjects in classroom teaching caused by excessive reliance on technology.

\section{CONCLUSION}

In the current context of big data, the dilemma of existing English teaching is more obvious. Among them, the more prominent teaching dilemma is the lack of teaching ecological environment. Therefore, it is necessary to focus on how to build a more harmonious and stable teaching ecological circle. Only in this way can the ecological teaching of college English be implemented and the practical effect of college English teaching be truly improved.

\section{REFERENCES}

[1] Cai, X. The Construction of College English Ecological Teaching Mode in the Era of Big Data. In Journal of Physics: Conference Series (2020, October, Vol. 1648, No. 4, p. 042061). IOP Publishing.

[2] Moxley, J. Big data, learning analytics, and social assessment. The Journal of Writing Assessment, 2013, $6(1), 1-10$

[3] Atiquzzaman, M. Big Data Analytics for Cyber-Physical System in Smart City: BDCPS 2020, 28 - 29 December 2020, Shanghai, China. Springer Nature.

[4] Liu, Y. College English Teaching Reform Driven by Big Data. In 2020 2nd International Conference on Machine Learning, Big Data and Business Intelligence (MLBDBI) 2020, October, pp. 300-304. IEEE.

[5] Liu, A., \& Kong, D. A Study on the College English Ecological Teaching Mode Based on Artificial Intelligence. In Proceedings of the 2020 International Conference on Cyberspace Innovation of Advanced Technologies, 2020, December, pp. 1-6.

[6] Wu, B. Construction of ecological teaching model for college English course under the background of internet plus. Educational Sciences: Theory \& Practice, 2018,18(6).

[7] Guo, J., \& Yu, S.. Evaluation model of college English teaching quality based on big data analysis. IOP Conference Series: Materials Science and Engineering (2020, February, Vol. 750, No. 1, p. 012077). IOP Publishing.

[8] Liu, Y. College English Teaching Reform Driven by Big Data. In 2020 2nd International Conference on Machine Learning, Big Data and Business Intelligence (MLBDBI), 2020, October, pp. 300-304. IEEE.

[9] Wei, X., \& Su, Z. Big Data-Assisted Analysis of College English Teacher Burnout Research and Emotional Intervention. Design Engineering, 2020, 870-885. 